\title{
Some important features of Renaissance Dramas: Themes, Style and Character Examination
}

\author{
Khakimova Gulnora Abdumalikovna
}

\begin{abstract}
Renaissance was one of the main periods of the growth in English literature, arts, economy, language development and others. Renaissance gave birth to individualism and worldliness, freed the minds of people. This topic is of great interest for scholars to analyze and find out new features. As it is stated in the article Renaissance period in English literature provoked drama and poetry, some pieces of them must be analyzed thoroughly.
\end{abstract}

Keywords: Renaissance, drama, poetry, theatre, culture, patriotism, spirit, revival of knowledge, plays, Jacobean period.

\section{INTRODUCTION}

The French word Renaissance means "rebirth." The Renaissance was a period in which artists and writers rejected the restrictions of the Middle Ages in order to develop new ideas, enthusiasm, and interests; there was a revival of knowledge, a new interest for learning. The results of this "rebirth" were a widespread study of art and literature, as well as dramas and plays.

The Renaissance in English literature provoked poetry and theatrical drama and shifted them to new heights. This period showed itself in the effort of the individual to free himself from the rigid institutions of the Middle Ages, feudalism and the church; and to assert his right to live, to think and to express himself in accordance with a more flexible way. It means that the Renaissance gave birth to individualism and worldliness. The Renaissance freed the minds of men from medievalism.

\section{MATERIALS AND METHODS}

The Renaissance spirit is marked one with a growing sense of beauty and an increasing enrichment of life. The Elizabethan age was called an age of Materialism and pure enjoyment of life. Beauty was one of the crucial points with the Elizabethans and women were regarded as adorable creatures. The theme of women gained an important place in the writings of the Renaissance writers.

\footnotetext{
Revised Manuscript Received on September 25, 2019

Khakimova Gulnora Abdumalikovna, A teacher of Arts faculty, Bukhara State University, Uzbekistan. Email: gulnora2404@mail.ru
}

Humanism was another topic for the writers and they were called Humanists who revived the knowledge of the Greek language and gave birth to a new culture. The humanist led by Erasmus began to take interest in life and in mankind. In the works of great writers man was discovering himself. Human life and human affairs began to occupy the writer's minds in greater measure as we find in Dante, Petrarch and Boccaccio.

The Renaissance did much to enlarge the boundaries of men's minds and create fresh ideas. It was an age of great curiosity and the thirst for knowledge. The theme of enthusiasm and romanticism was so powerful that scholars like Bacon took all knowledge to describe wonderful and the beautiful creatures, nature and the Elizabethans were the first and the greatest romantics of England.

The sense of the Renaissance spirit appeared in the Elizabethan literature which was marked by fullness of national life, patriotism, a passion for knowledge, a spirit of daring adventures and an ambition to achieve great things. The many sided intellectual activities of the Renaissance were full reflected in the literature of the 16th and 17 th centuries.

\section{DISCUSSION}

English Renaissance drama means the stage plays written and acted in the later 16th century and the first half of the 17th century, during the Renaissance period in England. This period in English history saw a great growth in drama as an art form and public entertainment. English Renaissance drama is sometimes called Elizabethan drama, some scholars and critics sometimes use the term Jacobean drama.

Playwrights worked in both the classic types of drama, tragedy and comedy. They also began their own type of history play, mainly about earlier English kings and the events of their reigns.

Renaissance dramatists created drama and developed this genre rapidly giving to the world masterpieces as Shakespeare's Hamlet, Macbeth, Twelfth Night, King Lear; Marlowe's Doctor Faustus, Edward II; John Webster's The Duchess of Malfi; Ben Johnson's 
Volpone, The Alchemist, Bartholomew Fair and others.

Jacobean plays differed from the plays of Shakespeare (Titus Andronicus), Kyd (The Spanish Tragedy), Marlowe (Tamburlaine), Lyly (Endymion) written in $1580 \mathrm{~s}$, those were considered to be outdated as they contained too long monologues giving background information about the characters, they had formal and declamatory style. However, Jacobean plays changed into more interactive, conversational style of writing, though they could contain long speeches but with different functions. Webster's Duchess of Malfi, Johnson's The Alchemist, Middleton's A Chaste Maid in Cheapside were of great examples of Jacobean style of writing.

In the Jacobean era the social tragedy genre had a different undertone. It was seen as a warning against social norms of a woman to destroy social bounds. As modern readers, we are able to criticize the society that prevents resistance of conventions and forces death of those who break the suppressive rules.

The status of women in the play is shown as they try to be powerful, equal with men. The Duchess used her social status to marry whom she wanted, but she preferred to have marital life, pure sexual interests for having children. Even though she knew she wouldn't survive in the life she asserted her authority demonstrating her bravity and confidence as "prince". Her proclamation to the very end "I am the Duchess of Malfi still" (4.2.125) reflects masculine traits of bravery , pride and rightful authority. Exclamation of her title maintains her power over her decisions to the very death. Duchess displayed control over her life in that period and it opened door for a revolution of women's empowerment. Through this character, Webster opposes current views of marriage and of women being seen as objects. The play is essential to shift from patriarchal views to the new idea of the role of women.

However, plotline can be analyzed differently as themes of the tragedy are various and opposite.

\section{CONCLUSION}

Jacobean society experiencing breakdown of free will, moral courage and positive vision of life, corrupted institutions were skillfully demonstrated by John Webster in this play. Awareness of societal division and corruption is nowhere more obvious than in Webster's most well known play, "The Duchess of Malfi". During this period, powerful women were considered dangerous and unnatural. Female dominance was accepted as social disorder. In patriarchal society all levels of the society looked towards a male figure holding supreme power, therefore, powerful women were disapproved by population. Political women must have had contradictory qualities of "manly" intelligence, motherly kind and merely obedient. In the Duchess's society, it was considered immoral and wrong for a noble woman to marry beneath her. Webster attempts to provoke thought through this socially unequal marriage and question what was considered morally acceptable. He himself does not pass moral judgment on her marriage, thus allowing for interpretations over the years to vary, with evolving times.

Renaissance dramatists created drama and developed this genre rapidly giving to the world masterpieces as Shakespeare's Hamlet, Macbeth, Twelfth Night, King Lear; Marlowe's Doctor Faustus, Edward II; John Webster's The Duchess of Malfi; Ben Johnson's Volpone, The Alchemist, Bartholomew Fair and others.

English Renaissance drama is worth reading and never loses its fame and attractiveness with its most important innovations as creating blank verse to develop English non dramatic poetry, using unrhymed iambic pentameter to make oral performance better, soliloquy to show the deep feelings of the character through monologues.

Renaissance drama opened the way to the later development of novel, journalism and other literary form.

\section{REFERENCES}

1. Braunmuller A.R. and Michael Hattaway." English Renaissance Drama", Cambridge University Press, 1992

2. Pacheco, Emma. The Power that Women Hold in The Duchess of Malfi. Final AE Project,2012

3. Wigham, Fred. "Sexual and Social Mobility in The Duchess of Malfi" Academic Search Premier.Web.18 Nov 2012.

4. Dympna, Callaghan, The Duchess of Malfi (New York: Sy.Martin's, 2000),p.4, citing Merry E. Weisner, Women and Gender in Early Modern Europe (Cambridge: Cambridge University Press,1993),p.166

5. Jankowsiki, Theodora A. "Defining/Confining the Duchess:Negotiating the Female Body in John Webster's The Duchess of Malfi" Studies in Philogy 90.87(1990):228-230. Academic Serach Premier. Web. 18 Nov 2012 . 